\title{
The role of signal transducer and activator of transcription 5 in the inhibitory effects of GH on adipocyte differentiation
}

\author{
H E Richter ${ }^{1}$, T Albrektsen ${ }^{2}$ and N Billestrup ${ }^{1,3}$ \\ ${ }^{1}$ Department of Signal Transduction, Novo Nordisk A/S, Novo Allé, DK-2880 Bagsvaerd, Denmark \\ ${ }^{2}$ Department of Transcription Biology, Novo Nordisk A/S, Novo Allé, DK-2880 Bagsvaerd, Denmark \\ ${ }^{3}$ Steno Diabetes Centre, Niels Steensensvej 6, DK-2820 Gentofte, Denmark \\ (Requests for offprints should be addressed to N Billestrup, Steno Diabetes Centre, Niels Steensensvej 6, NSK2.023, DK-2820 Gentofte, Denmark; \\ Email:nbil@steno.dk)
}

\begin{abstract}
GH inhibits primary rat preadipocyte differentiation and expression of late genes required for terminal differentiation. Here we show that $\mathrm{GH}$-mediated inhibition of fatty acid-binding protein aP2 gene expression correlates with the activation of the Janus kinase-2/signal transducer and activator of transcription (STAT)-5 signalling pathway. Within minutes of treatment, GH induced the tyrosine phosphorylation, nuclear localization and DNA binding of STAT5. Importantly, there was no evidence that STAT5 acted via an interaction with peroxisome proliferator-activated receptor $\gamma$. To further understand the mechanism of STAT5 action, we reconstituted the inhibition of aP2 in a non-adipogenic cell line. Using this system, we showed that the ability of $\mathrm{GH}$ to inhibit a $520 \mathrm{bp}$ aP2 reporter was largely dependent upon the presence of either STAT5A or STAT5B. Mutant analysis confirmed that the tyrosine phosphorylation of STAT5 was essential for this signalling. However, STAT5's C-terminal transactivation domain was fully dispensable for this inhibition. Taken together, these data confirm a key regulatory role of STAT5 in adipose tissue and point to STAT5 as the repressing modulator of $\mathrm{GH}$-mediated inhibition in primary preadipocytes.
\end{abstract}

Journal of Molecular Endocrinology (2003) 30, 139-150

\section{Introduction}

Differentiation of preadipocytes into mature adipocytes is controlled by a well-established sequential cascade of transcriptional events (Christy et al. 1989, Freytag et al. 1994, Fajas et al. 1999, Rosen et al. 2000), for which the nuclear hormone receptor, peroxisome proliferator-activated receptor $\gamma(\operatorname{PPAR} \gamma)$ is a key regulator (Graves et al. 1992, Tontonoz et al. 1994a,b,c, Rosen et al. 1999, $\mathrm{Wu}$ et al. 1999). The transcriptional activity of PPAR $\gamma$ is dependent both on heterodimerization with the retinoid $\mathrm{X}$ receptor $\alpha(\mathrm{RXR} \alpha)$ and on activation by either one of its natural ligands such as 15 -deoxy- $\Delta^{12,14}$-prostaglandin J2 or by highaffinity agonists of the anti-diabetic thiazolidinedione group of compounds (Forman et al. 1995,
Lehmann et al. 1995). Upon ligand binding, a number of transcriptional co-activators, such as the steroid receptor co-activator, PPAR $\gamma$-binding protein, thyroid hormone receptor-associated protein 220, and adenovirus E1A-associated protein p300/ CREB-binding protein $(\mathrm{CBP})$ are recruited to the PPAR $\gamma /$ RXR $\alpha$ complex (Chakravarti et al. 1996, Kamei et al. 1996, Zhu et al. 1997, Gelman et al. 1999, Ge et al. 2002). Genes that are regulated by liganded PPAR $\gamma$ include the fatty acid-binding protein aP2 (Tontonoz et al. 1994a,b), phosphoenolpyruvate carboxykinase (Tontonoz et al. 1995), and lipoprotein lipase (Schoonjans et al. 1996).

Growth hormone $(\mathrm{GH})$ has been shown to play a critical role in regulating adipose tissue homeostasis in vivo (Donahue \& Beamer 1993, Pomp et al. 1996, 
Eisen et al. 1998, Ikeda et al. 1998, Lauterio et al. 1998, Frick et al. 2001). GH deficiency in humans is associated with obesity and increased adipocyte size and number, and treatment with GH restores adipose mass to normal levels (Salomon et al. 1989, Johannsson et al. 1997). Consistent with these observations, GH inhibits primary adipocyte differentiation in vitro (Wabitsch et al. 1996, Hansen et al. 1998). However, in other model systems, including 3T3-F442A, NIH-3T3 and 3T3-L1 cells, $\mathrm{GH}$ and the related hormone prolactin act as positive regulators of the adipogenic conversion (Morikawa et al. 1982, Clarkson et al. 1995, Xu et al. 1995, Nanbu-Wakao et al. 2000, 2002). Thus, considerable questions remain about the role and mechanism of action of $\mathrm{GH}$ in adipogenesis.

In this study we have focused our attention on establishing the role of $\mathrm{GH}$-mediated inhibition of PPAR $\gamma$-activated transcription and adipocyte differentiation. We have previously demonstrated that $\mathrm{GH}$ does not affect expression of adipocyte determination and differentiation factor 1/sterol response element-binding protein 1 mRNA (Hansen et al. 1998). However, GH causes an approximately $50 \%$ reduction in the levels of PPAR $\gamma$ mRNA and reduces the levels of aP2, fatty acid synthase and hormone-sensitive lipase mRNA by up to $80 \%$ (Hansen et al. 1998). Based on these findings, we propose that $\mathrm{GH}$ exerts its main inhibitory effect on genes required for terminal differentiation.

GH signalling has been shown to activate several members of the signal transducer and activator of transcription (STAT) family, including STAT1, 3, 5A and 5B (Meyer et al. 1994, Campbell et al. 1995, Gronowski et al. 1995, Smit et al. 1996). In particular, STAT5A and B are believed to be major downstream targets of GH (Wood et al. 1995, Smit et al. 1996, Teglund et al. 1998). Binding of $\mathrm{GH}$ to the $\mathrm{GH}$ receptor (GHR) results in receptor dimerization and rapid activation of the GHRassociated Janus kinase 2 (JAK2) leading to phosphorylation of both the GHR and JAK2 (Carter-Su et al. 1989, de Vos et al. 1992, Argetsinger et al. 1993). Upon these phosphorylation events, STAT5 binds to the GHR and is phosphorylated on tyrosine residues enabling it to dimerize with other phosphorylated STAT5 proteins via SH2 domains. The STAT5 dimer then translocates to the nucleus where it binds specific DNA elements. Once bound to DNA, the STAT5 dimer can mediate either gene activation or gene repression depending upon the promoter and/or cellular context (Galsgaard et al. 1996, Stocklin et al. 1996, Luo \& Yulee 1997, Pfitzner et al. 1998, Zhou \& Waxman 1999a,b, Luo \& Yu-Lee 2000, reviewed in Ihle 2001).

STAT5 has been implicated in the regulation of adipogenesis in a variety of different model systems (Stephens et al. 1996, 1999, Yarwood et al. 1999, Harp et al. 2001, Nanbu-Wakao et al. 2000, 2002). Given this finding, we investigated the role of STAT5 in GH signalling in primary preadipocytes. In this report, we show that GH stimulates STAT5 signalling in primary preadipocytes. Moreover, the ability of $\mathrm{GH}$ to inhibit transcription of an aP2 reporter is STAT5-dependent and requires tyrosine phosphorylation but not downstream signalling by STAT5. These results suggest that GH-induced STAT5 signalling in primary preadipocytes represses transcription of genes required for terminal differentiation.

\section{Materials and methods}

\section{Cell culture and differentiation}

All reagents were purchased from GIBCO-BRL Life Technologies unless otherwise is noted. Primary preadipocytes were isolated as previously described (Hansen et al. 1998). For preparation of nuclear, cytoplasmic and whole cell extracts cells were seeded at a density of $1.25 \times 10^{6}$ cells per $92 \mathrm{~mm}$ dish. After 2 days of culture the medium was changed to differentiation medium: DMEM with $1000 \mathrm{mg} / \mathrm{l}$ D-glucose and Glutamax/Ham's F12 $(1: 1 \mathrm{v} / \mathrm{v})$ supplemented with $15 \mathrm{mM}$ $\mathrm{NaHCO}_{3}, 15 \mathrm{mM}$ Hepes, $33 \mu \mathrm{M}$ biotin (Sigma), $17 \mu \mathrm{M}$ pantothenate (Sigma), 100 units/ml penicillin, $100 \mu \mathrm{g} / \mathrm{ml}$ streptomycin (Pen/Strep), $2 \mathrm{mM}$ glutamine, $10 \mu \mathrm{g} / \mathrm{ml}$ transferrin (Sigma), $1 \mu \mathrm{M}$ insulin (Novo Nordisk A/S, Bagsvaerd, Denmark), and $200 \mathrm{pM}$ triiodothyronine $\left(\mathrm{T}_{3}\right)$ (Sigma). The day of induction of differentiation was referred to as day 0. HEK 293 cells were cultured in DMEM with $4500 \mathrm{mg} / \mathrm{l}$ D-glucose and Glutamax, supplemented with $10 \%$ heat-inactivated fetal calf serum (FCS) and Pen/Strep. Primary preadipocytes and HEK 293 cells were cultured at $37{ }^{\circ} \mathrm{C}$ in a humidified atmosphere containing $5 \% \mathrm{CO}_{2}$ in air. For all GH stimulations, recombinant human 
GH (Novo Nordisk) was used to a final concentration of $20 \mathrm{nM}$.

\section{Northern blot analysis}

Total RNA was isolated from primary preadipocytes using TRIzol Reagent (Invitrogen) according to the manufacturer's instruction. Twenty micrograms of RNA were fractionated on a denaturing gel containing $1 \%$ agarose, $20 \mathrm{mM}$ Mops, $5 \mathrm{mM}$ sodium acetate, 6\% formaldehyde and $1 \mathrm{mM}$ EDTA, transferred to a Hybond $\mathrm{N}+$ membrane (Amersham Pharmacia Biotech), hybridized using Express Hyb (Clontech Laboratories, Inc., Palo Alto, CA, USA) according to manufacturer's instructions, and the results visualized by autoradiography.

\section{Plasmids}

The $520 \mathrm{bp}$ aP2-chloramphenicol acetyl transferase (CAT) reporter construct was kindly provided by Dr B M Spiegelman (Dana-Farber Cancer Institute, Boston, MA, USA). It contains the PPAR $\gamma / \mathrm{RXR}$-responsive adipocyte regulatory element 7 (ARE7) site linked to the region -63 to +21 containing a partially deleted CCAAT box, a TATA box and a transcriptional start site in the aP2. Plasmids encoding the human $\operatorname{RXR} \alpha$ and PPAR $\gamma$ were kindly provided by Dr J Fleckner (Novo Nordisk). The expression vector mouse STAT5 $A^{\Delta 749}$, sheep STAT5A ${ }^{\text {Y694F }}$ and sheep MGF/STAT5A were kindly given by Dr Bernd Groner (Georg Speyer Haus, Frankfurt, Germany). Plasmids encoding human p300 and mouse CBP were kindly provided by Dr R Goodman (Vollum Institute, Portland, OR, USA). The rat GHR was kindly given by Dr G Norstedt (Karolinska Institute, Stockholm, Sweden). Expression vector encoding $\beta$-galactosidase, pCH110, was obtained from Pharmacia Inc.

\section{Transient transfection assays, $\beta$-galactosidase and CAT assays}

HEK 293 cells $\left(3-4 \times 10^{5}\right)$ were seeded in $58 \mathrm{~mm}$ tissue culture dishes (Nunc, Roskilde, Demnark) in DMEM with high glucose supplemented with $10 \%$ heat-inactivated FCS and Pen/Strep. Prior to transfection media were replaced with DMEM containing carbon-stripped FCS $(2 \mathrm{~g}$ active carbon (Merck, Darmstadt, Germany) $/ 50 \mathrm{ml}$ FCS was incubated $2 \mathrm{~h}$ at $4{ }^{\circ} \mathrm{C}$, followed by centrifugation and filtration). Cells were transfected using calcium phosphate as described previously (Chen \& Okayama 1987) with the following amounts for each expression vector: $0.5 \mu \mathrm{g} 520 \mathrm{bp}$ aP2-CAT, $0.5 \mu \mathrm{g}$ SV40- $\beta$-gal and in various combinations co-transfected with $1.0 \mu \mathrm{g} \operatorname{RXR} \alpha, 0.5 \mu \mathrm{g} \operatorname{PPAR} \gamma$, $0.5 \mu \mathrm{g}$ MGF-STAT5A, $1.0 \mu \mathrm{g} \quad \mathrm{STAT}_{5 A^{\Delta 749}}$, $1 \cdot 0 \mu \mathrm{g} \quad \mathrm{STAT}_{5 \mathrm{~A}}{ }^{\mathrm{Y} 694 \mathrm{~F}}$ and $2 \cdot 25 \mu \mathrm{g}$ GHR. To ensure equal amounts of DNA, empty pcDNA3 $1+$ was added up to a total of $10 \mu \mathrm{g}$. Following transfection cells were stimulated with $0 \cdot 1 \mu \mathrm{M}$ BRL49653 (Novo Nordisk A/S) and cultured in the absence or presence of $20 \mathrm{nM} \mathrm{GH}$. Cells were harvested approximately $36 \mathrm{~h}$ after transfection. All transfections were performed as duplicate experiments and repeated two to four times. The CAT assay was performed as previously described (Galsgaard et al. 1996). Twenty microlitres of each cell extract were mixed with $1 \mathrm{ml} \beta$-gal buffer supplemented with $\beta$-mercaptoethanol and O-nitrophenyl-beta-D-galactopyranoside (ONPG). The reaction was incubated at $37^{\circ} \mathrm{C}$ for approximately $2 \mathrm{~h} . \mathrm{OD}_{420}$ was measured and used for normalization of transfection efficiency.

\section{Nuclear, cytoplasmic and whole cell extracts}

Primary preadipocytes were grown in $92 \mathrm{~mm}$ plates and isolated on approximately day 5 of differentiation. Cells were stimulated with $20 \mathrm{nM}$ GH for $15 \mathrm{~min}$ prior to isolation, which was done as previously described (Hansen et al. 1998). The supernatant containing the cytoplasmic proteins was recovered and used in Western blot analysis. The nuclei were resuspended in hypertonic buffer containing $20 \mathrm{mM}$ HEPES (pH 7.9), $10 \mathrm{mM} \mathrm{KCl}$, $1 \mathrm{~mm} \mathrm{MgCl}_{2}, 1 \mathrm{mM}$ EDTA and $400 \mathrm{mM} \mathrm{NaCl}$, incubated for $30 \mathrm{~min}$ on a rocking bench at $4{ }^{\circ} \mathrm{C}$ and subsequently centrifuged at $20000 \boldsymbol{g}$ for $30 \mathrm{~min}$ at $4{ }^{\circ} \mathrm{C}$. Extracts were frozen in liquid nitrogen and stored at $-80{ }^{\circ} \mathrm{C}$. Whole cell extracts were isolated from primary preadipocytes after 2 days of culture. Prior to isolation cells were stimulated with $20 \mathrm{nM} \mathrm{GH}$ as indicated on the Figure. Cells were washed in ice-cold PBS and lysed in $0.5 \mathrm{ml} / 90 \mathrm{~mm}$ dish PBS containing $1 \%$ NP40 and $0 \cdot 1 \%$ SDS. The lysis buffer was supplemented with $1 \mathrm{mM}$ dithiothreitol, $0.5 \mathrm{mM}$ 
4-(2-aminoethyl)-benzene sulphonyl fluoride hydrochloride, $1 \mathrm{mM} \mathrm{Na} \mathrm{NO}_{4}$ and protease inhibitors $(1 \mu \mathrm{g} / \mathrm{ml}$ leupeptin and $1 \mu \mathrm{g} / \mathrm{ml}$ aprotinin) just before use. Cells were lysed on ice for $30 \mathrm{~min}$ and the whole cell extract recovered by centrifugation at $20000 \boldsymbol{g}$ for $30 \mathrm{~min}$ and stored at $-80{ }^{\circ} \mathrm{C}$. Protein concentrations were measured using BioRad protein assay according to manufacturer's instructions (Bio-Rad Laboratories, Munich, Germany).

\section{Immunoprecipitation}

Whole cell extract from primary preadipocytes was incubated overnight at $4{ }^{\circ} \mathrm{C}$ with $2 \mu \mathrm{g}$ anti-STAT5 (sc-835; Santa Cruz Biotechnology Inc., Santa Cruz, CA, USA) followed by a $2 \mathrm{~h}$ incubation with protein G-Sepharose. Precipitates were washed three times in lysis buffer (PBS containing 1\% NP40 and $0 \cdot 1 \%$ SDS) and proteins were eluted with $1 \times$ SDS sample buffer.

\section{Gel shift assay}

Gel shift assays were performed as previously described (Galsgaard et al. 1996, Hansen et al. 1998). Briefly, for PPAR $\gamma / \operatorname{RXR} \alpha$ DNA binding the ARE7 (5'-gatcTGTGAACTGTGATCGAG TAAG) (Tontonoz et al. 1994b) was used and for STAT5 DNA binding the Spi2-1-GLE1 (5'-agctATGTTCTGAGAAAATG) (Hansen et al. 1997) was used. As non-specific competitors unlabelled M67 (5'-agctTCATTTCGCGTAAAT CCCTA), $\alpha \mathrm{CG}$ (5'-agctTTTTACGATGAC-GTCAATTTGATG), or E/GRE (5'-agctATTAAG TGGATTGTTGTGGA) (Life Technologies) were used. All oligonucleotides were labelled with $\left[\alpha-{ }^{32} \mathrm{P}\right] \mathrm{dATP}$ (Amersham Biosciences) in a fill-in reaction using DNA polymerase (Klenow fragment) (Promega). Three micrograms of nuclear extracts from primary preadipocytes were used in each reaction. For super shift analysis $2 \mu \mathrm{g}$ of the indicated antibodies were used: anti-STAT5 (sc-835; Santa Cruz Biotechnology), anti-PPAR $\gamma$ (sc-1984, sc-7273; Santa Cruz Biotechnology) or anti-PPAR $\gamma$ (PA3-820, PA3-821; Affinity BioReagents Inc., Golden, CO, USA). Free and bound probe were separated on a $6 \%$ DNA retardation gel (\#EC63652; Invitrogen) by electrophoresis, dried and visualized by autoradiography.

\section{Western blot analysis}

For detection of GH-induced tyrosine phosphorylation of STAT5, proteins were separated by electrophoresis on a precast NuPAGE 4-12\% Bis/Tris Gel (\#NP0322; Invitrogen) with NuPAGE MOPS SDS running buffer (\#NP0001; Invitrogen) using the Novex electrophoresis system and blotted to PVDF membranes (\#LC2002) using a Novex blotting system (Invitrogen). For analysis of cellular localization of STAT5, proteins were separated by SDS-PAGE (4\% stacking gel, $7 \cdot 5 \%$ running gel) and transferred by electroblotting to ECL nitrocellulose membranes (Amersham Pharmacia Biotech). Membranes were blocked for $1 \mathrm{~h}$ in $5 \%$ non-fat dry milk in PBST (PBS containing $0 \cdot 1 \%$ Tween) and incubated with primary antibody overnight at $4{ }^{\circ} \mathrm{C}$. Membranes were washed three times for $15 \mathrm{~min}$ in PBST and incubated with secondary horseradish peroxidase (HRP)-linked antibodies for $2 \mathrm{~h}$ at room temperature. Proteins were visualized using an ECL detection system (Amersham Pharmacia Biotech). Primary antibodies were used in following dilutions: antiSTAT5 (sc-835; Santa Cruz Biotechnology) 1:2000, phosphotyrosine-HRP (\#61-5820; Zymed, South San Francisco, CA, USA) 1:1000. For control of equal amounts of protein the phosphotyrosine blot was re-probed with anti-STAT5 antibody.

\section{Results}

\section{GH inhibits expression of aP2 mRNA}

Our previous study has shown that GH inhibits adipogenic genes required for terminal differentiation of primary preadipocytes (Hansen et al. 1998). In order to demonstrate the effect of $\mathrm{GH}$ on aP2 mRNA expression we performed Northern blot analysis analysing total RNA from primary preadipocytes differentiated in the absence or presence of GH. Consistent with previously reports (Hansen et al. 1998), GH down-regulated expression of aP2 mRNA (Fig. 1). We found that primary preadipocytes kept in a serum-free medium only increased expression of aP2 modestly whereas cells that were induced to differentiate using insulin and thyroid hormone increased aP2 expression 23-fold from day 0 to day 7 (Fig. 1). On day 7 of differentiation, aP2 expression was reduced from 23 -fold to 5 -fold in cells that had 
A.

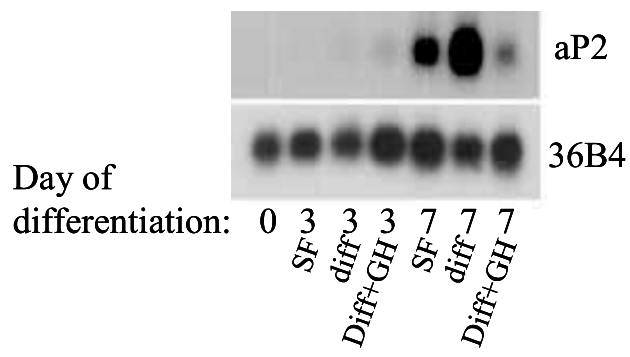

B.

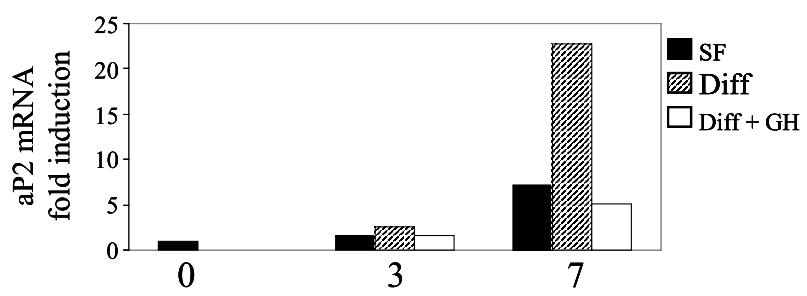

Day of differentiation:

Figure 1 Effect of GH on aP2 mRNA expression. Northern blot analysis with total RNA ( $20 \mu \mathrm{g}$ per lane) from primary rat preadipocytes cultured either in serum-free media (SF), differentiated in serum-free media supplemented with $1 \mu \mathrm{M}$ insulin and $15 \mathrm{pm} \mathrm{MT}_{3}$ (Diff) or differentiated in the presence of $20 \mathrm{nM} \mathrm{GH}$ (Diff $+\mathrm{GH})$. RNA was isolated on day 0,3 and 7 for differentiation. (A) Blots were hybridized with specific radiolabelled cDNA fragments for aP2 (top panel), and 36B4 (lower panel). (B) Amounts of mRNA were normalized to the expression levels of 36B4 mRNA and quantification of aP2 mRNA is illustrated as fold induction as a function of days of differentiation $(n=3)$.

been differentiated in the presence of $\mathrm{GH}$, which was even lower than the expression found under basal serum-free conditions over the same time course.

\section{GH activates STAT5 signalling in primary preadipocytes}

STAT5 is known to be an important downstream target of GH (Teglund et al. 1998) and has also been implicated in the regulation of adipogenesis. We therefore investigated whether $\mathrm{GH}$ activates STAT5 signalling in primary preadipocytes (Fig. 2). In order to do this, we analysed $\mathrm{GH}$-activated tyrosine phosphorylation of STAT5 by stimulating primary preadipocytes with $\mathrm{GH}$ for $0,10,20$ and 40 min (Fig. 2A). No tyrosine phosphorylation of STAT5 was observed in the absence of GH.
However, after 10 min of stimulation STAT5 was activated as identified by anti-phosphotyrosine Western blot (Fig. 2A, lane 2). Activation by GH was transient and decreased rapidly. After $40 \mathrm{~min}$ of stimulation only a weak band was observed (Fig. 2A).

To determine if $\mathrm{GH}$ activation also led to nuclear translocation of STAT5, we isolated nuclear and cytoplasmic extracts from primary preadipocytes cultured in either the presence or absence of $\mathrm{GH}$ for $10 \mathrm{~min}$ (Fig. 2B). In agreement with the phosphorylation pattern, we detected only small amounts of STAT5 in the nuclei from non-stimulated cells (Fig. 2B, lane 1) whereas the intensity of the STAT5 band in nuclear extracts was increased dramatically upon stimulation with GH (Fig. 2B, lane 2), indicating that STAT5 translocated to the nucleus in response to $\mathrm{GH}$. In correlation with this, cytoplasmic extracts isolated from non-stimulated cells showed a relatively higher amount of STAT5 (Fig. 2B, lane 3) than cytoplasmic extracts from cells that had been stimulated with GH (Fig. 2B, lane 4). The appearance of STAT5 as a doublet in Fig. 2B might reflect the presence of both STAT5A and STAT5B in the extracts, although specific antibodies would be required to resolve this issue. The lack of a doublet in Fig. 2A could be caused by the longer exposure of this blot or the fact that a slightly different SDS-PAGE system with higher resolution was used for the blot shown in Fig. 2B.

Given that we observed phosphorylation and nuclear translocation of STAT5 in response to GH, we next examined whether GH stimulated DNA binding of STAT5 (Fig. 2C). As shown, incubation of nuclear extracts, isolated from primary preadipocytes stimulated with $\mathrm{GH}$ for $10 \mathrm{~min}$, with an oligonucleotide containing a STAT5 response element resulted in a protein-DNA complex (Fig. $2 \mathrm{C}$, lane 3). The specificity of the complex was demonstrated by competition with increasing amounts of either cold specific oligonucleotide Spi2-1-GLE or non-specific oligonucleotide $(\alpha \mathrm{GG})$ (Fig. 2C, lanes 4 and 5). The presence of STAT5 in the retarded complex was further confirmed upon pre-incubation of nuclear extracts with antiSTAT5 antibody, resulting in a super-shifted band (Fig. 2C, lane 8).

It has been previously been shown that prolactin-induced STAT5A can act as a functional repressor of glucocorticoid receptor (GR)-activated 
A.

Whole cell extract
$\mathrm{GH}: \quad 0^{\prime} \quad 10^{\prime} \quad 20^{\prime} \quad 40^{\prime}$
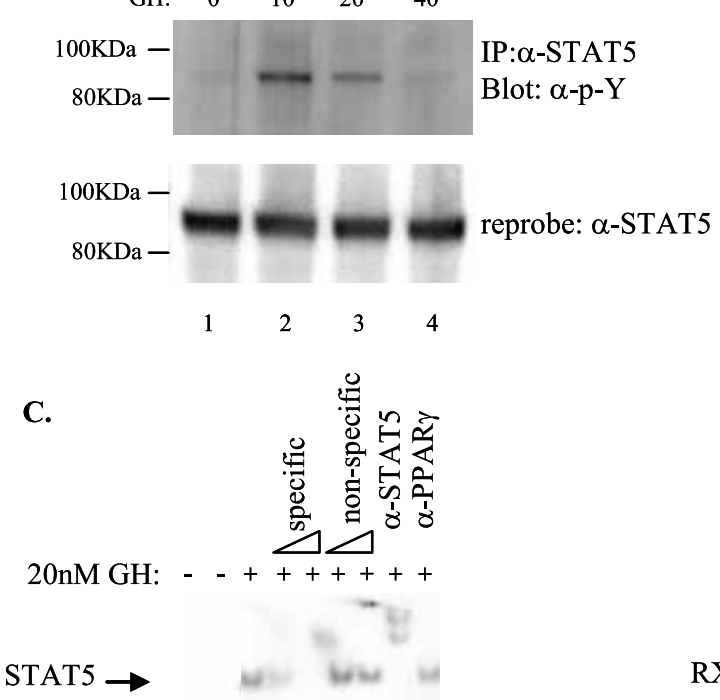

$\begin{array}{lllllllll}1 & 2 & 3 & 4 & 5 & 6 & 7 & 8 & 9\end{array}$

STAT5-responsive probe (32P-Spi2.1-GLE)
B. Nuclear Cytoplasmic

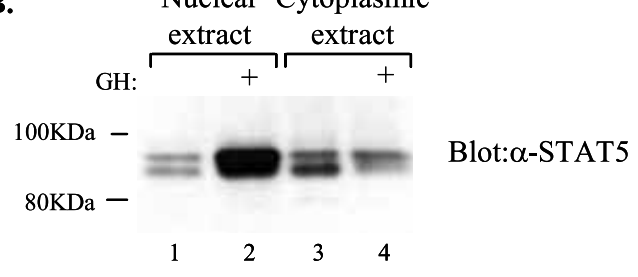

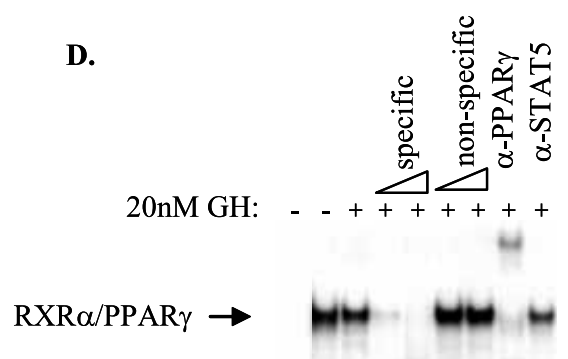

$\begin{array}{lllllllll}1 & 2 & 3 & 4 & 5 & 6 & 7 & 8 & 9\end{array}$

$\operatorname{PPAR} \gamma$-responsive probe

(32P-ARE7)

Figure $2 \mathrm{GH}$ activates STAT5 signalling in primary preadipocytes. (A) Western blot analysis of whole cell extract from primary rat preadipocytes stimulated with $\mathrm{GH}$ for $0,10,20$ and $40 \mathrm{~min}$. STAT5 was subsequently immunoprecipitated with anti-STAT5 antibody overnight at $4{ }^{\circ} \mathrm{C}$. The membrane was incubated with an anti-phosphor-tyrosine antibody and subsequently re-probed with an anti-STAT5A/B antibody to verify equal STAT5 protein in each lane. (B) Western blot analysis of nuclear extracts and cytoplasmic extracts from primary rat preadipocytes with an anti-STAT5A/B antibody. Primary preadipocytes were either not stimulated (lanes 1 and 3) or stimulated for 10 min with $20 \mathrm{nM} \mathrm{GH}$ (lanes 2 and 4) prior to isolation of nuclear extracts and cytoplasmic extracts. Figures represent the results of two independent experiments. Gel shift analysis of STAT5 and PPAR $\gamma$ binding to radiolabelled Spi-GLE (C) or ARE7 (D) oligonucloetides. Probes were incubated in either the absence $(C$ and $D$, lane 1$)$ or presence of $3 \mu \mathrm{g}$ nuclear extracts from primary rat preadipocytes not stimulated (C and D, lane 2) or stimulated 10 min with $20 \mathrm{nM} \mathrm{GH}$ (C and D, lanes 3-9). Unlabelled specific oligonucleotide was included in the incubation time at $100 \times$ and $1000 \times$ molar excess (C and D, lanes 4 and 5) and likewise for non-specific oligonucleotide ( $C$ and $D$, lanes 6 and 7 ). Nuclear extracts were pre-incubated for $30 \mathrm{~min}$ at $4{ }^{\circ} \mathrm{C}$ with antibodies as indicated above the gels. Figures represent the results of three independent experiments.

transcription by direct interaction with the GR (Stocklin et al. 1996). Given this finding, we examined whether PPAR $\gamma$ was present in the STAT5-DNA complex. Initially, we pre-incubated the nuclear extract with an anti-PPAR $\gamma$ antibody but this had no detected effect on the mobility of the protein-DNA complex (Fig. 2C, lane 9). To further test whether GH stimulated direct complex formation between STAT5 and PPAR $\gamma$, we also tested the nuclear extracts for their ability to bind to the PPAR $\gamma$-responsive element, ARE7 (Fig. 2D). As expected, we detected significant binding activity in the differentiating preadipocytes (Fig.
2D, lane 2). However, the intensity and mobility of the band was not altered in the presence of $\mathrm{GH}$ (Fig. 2D, lanes 3, 6 and 7). The specificity of the DNA-PPAR $\gamma$ complex was demonstrated by competition with either cold specific ARE7 oligonucleotide or unspecific oligonucleotide (E/GCR) (Fig. 2D, lanes 4-7). Furthermore, pre-incubation of nuclear extracts with an antibody against PPAR $\gamma$ super-shifted the specific band, indicating the presence of PPAR $\gamma$ in this complex (Fig. 2D, lane 8). Most importantly, pre-incubation of nuclear extracts with anti-STAT5 antibody did not change the mobility of the PPAR $\gamma$ complex, 
indicating that STAT5 is not present together with PPAR $\gamma$ in the protein-DNA complex (Fig. 2D, lane 9). Taken together, these data demonstrate that GH activates STAT5 signalling in primary preadipocytes and induces STAT5 DNA binding; however, no interaction between STAT5 and PPAR $\gamma$ was detected.

\section{GH inhibits PPAR $\gamma$-activation of the aP2 promoter in a STAT5-dependent manner}

Our results with primary preadipocytes showed that STAT5 is regulated in primary preadipocytes in response to GH. In order to determine whether STAT5 is required for GH-mediated inhibition of the aP2 promoter, we used HEK 293 cells transiently transfected with the $520 \mathrm{bp}$ aP2-CAT reporter construct containing the PPAR $\gamma / \mathrm{RXR} \alpha-$ binding site ARE7 (Graves et al. 1991). To validate the HEK 293 cells as a model system for aP2 promoter regulation, we transiently transfected the HEK 293 cells with the 520 bp aP2-CAT reporter either alone or together with PPAR $\gamma 2$ and RXR $\alpha$ in the presence of BRL49653. Co-transfection of $\operatorname{PPAR} \gamma$ and $\operatorname{RXR} \alpha$ and simultaneous stimulation with BRL49653 led to a 15-fold increase in transcriptional activity (Fig. 3A). To reconstitute the STAT5 signalling pathway we transiently transfected HEK 293 cells with expression vectors encoding the GHR and STAT5A, together with PPAR $\gamma 2$, RXR $\alpha$ and the $520 \mathrm{bp}$ aP2-CAT reporter (Fig. 3A). Expression of GHR together with PPAR $\gamma 2 / \mathrm{RXR} \alpha$ and BRL49653 led to an additional increase in CAT activity from 15-fold to 20-fold (Fig. 3A, bar 3), which was reduced to 6 -fold in the presence of GH (Fig. 3A, bar 4). The transcriptional activity measured in HEK 293 cells transfected with the $520 \mathrm{bp}$ aP2-CAT reporter, PPAR $\gamma 2$, RXR $\alpha$, GHR and STAT5A (Fig. 3A, bar 3) was arbitrarily set to $100 \%$ (Fig. 3B, bar 1). In the absence of STAT5A or STAT5B stimulation by $\mathrm{GH}$ had no effect on the $520 \mathrm{bp}$ aP2 promoter. Upon co-transfection with STAT5A or STAT5B and simultaneous stimulation with $20 \mathrm{nM} \mathrm{GH}$, the relative CAT activity was decreased from $100 \%$ to $\sim 40 \%$ for STAT5A and to $30 \%$ for STAT5B (Fig. 3B, bars 4 and 6). We next tested if STAT1 or/and STAT3 could mediate inhibition by GH. However, neither expression of STAT1 or STAT3, nor of both STAT1 and STAT3 combined, led to a reduction in the transcriptional activity (data not shown), suggesting that $\mathrm{GH}$ inhibits aP2 transcription through a mechanism that requires specifically the presence of STAT5A or STAT5B.

Having established that GH-mediated inhibition of the $520 \mathrm{bp}$ aP2 promoter is STAT5-dependent, we were able to use this model system to investigate the potential mechanisms of repression (Fig. 3C). First, the importance of tyrosine residue Y694 in STAT5A was analysed. This residue is phosphorylated in response to $\mathrm{GH}$ and required for dimerization of STAT5 proteins and hence translocation to the nucleus (Gouilleux et al. 1994, Smit et al. 1997). To that end, HEK 293 cells were transfected with the $520 \mathrm{bp}$ aP2-CAT reporter construct together with PPAR $\gamma 2$, RXR $\alpha$, GHR and either wild-type STAT5A (STAT5A ${ }^{\text {wt }}$ ) (Fig. 3C, bars 1 and 2) or STAT5A ${ }^{\mathrm{Y} 694 \mathrm{~F}}$ (Fig. 3C, bars 3 and 4 ) in the absence or presence of $20 \mathrm{nM}$ GH (Fig. 3C, bars 2 and 4). STAT5A ${ }^{\mathrm{Y} 694 \mathrm{~F}}$ was unable to mediate the inhibitory effect of GH (Fig. 3C, bar 4), indicating that tyrosine phosphorylation is essential for GH-mediated inhibition via STAT5A.

We also wished to establish whether inhibition of aP2 transcription required STAT5's transcriptional activity. To address this issue, we utilized a dominant negative C-terminal truncated mutant, STAT $5 \mathrm{~A}^{\Delta 749}$, in which the transactivating domain had been deleted (Fig. 3C, bars 5 and 6). This STAT5 mutant is able to dimerize with STAT5 $\mathrm{A}^{\mathrm{wt}}$, translocate to the nucleus and bind DNA but it cannot activate transcription. Surprisingly, addition of $\mathrm{GH}$ in context with the truncated STAT5A ${ }^{\Delta 749}$ resulted in $62 \%$ inhibition of CAT activity (Fig. 3G, bar 6) relative to non-stimulated cells transfected with $\operatorname{STAT} 5 \mathrm{~A}^{\Delta 749}$ (Fig. 3C, bar 5). Together, these data suggest that GH down-regulates the aP2 promoter activity through a mechanism that requires the presence of STAT5. Moreover, activation of STAT5 by tyrosine phosphorylation is needed but downstream activation of transcription by STAT5 is not required for the inhibitory effect of $\mathrm{GH}$.

\section{Increasing concentrations of p300 partly reverse the inhibitory effect of $\mathrm{GH}$}

STAT5 has been shown to repress transcription through a variety of different mechanisms depending upon both the promoter and cellular context. In the case of STAT5-mediated inhibition of 


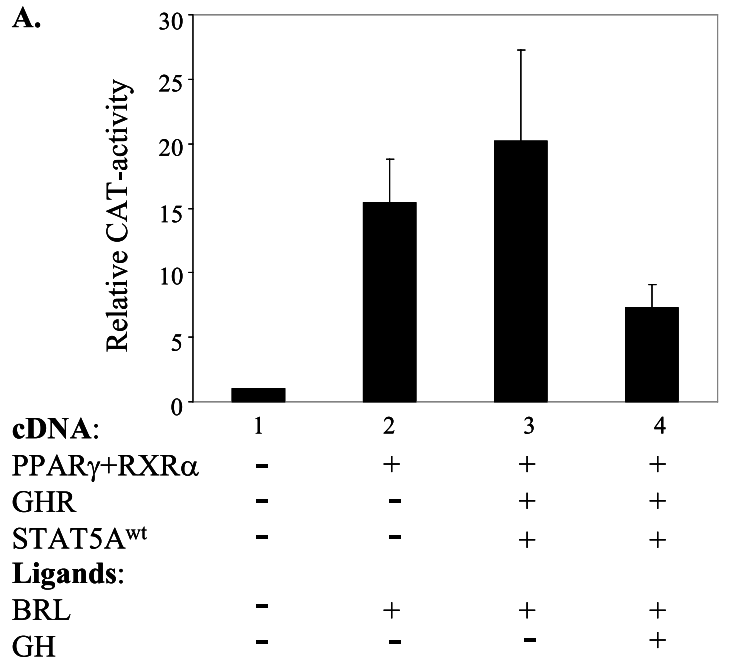

B.

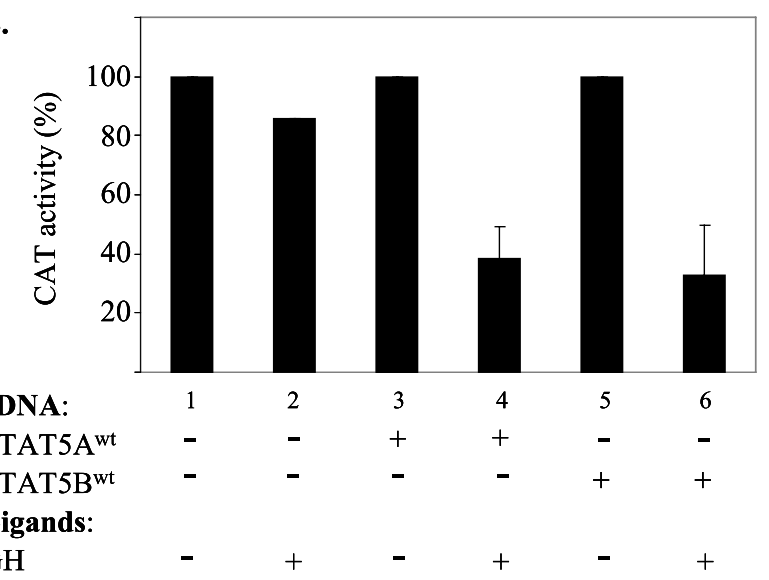

C.

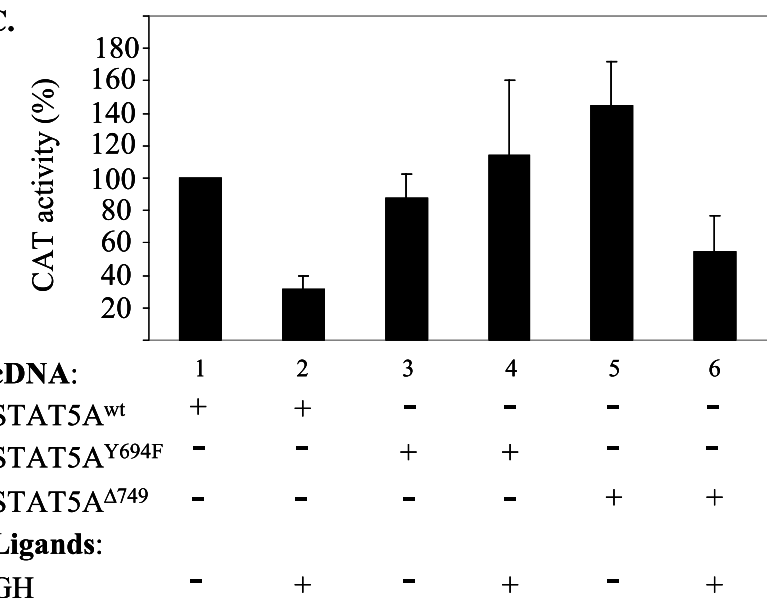

nuclear factor- $\kappa \mathrm{B}(\mathrm{NF}-\kappa \mathrm{B})$ signalling this repression can be overridden by increasing concentrations of the co-activator, p300 (Luo \& Yu-Lee 2000). Given this finding, we tested whether expression of p300 could rescue PPAR $\gamma$-activated transcription of the 520 bp aP2-CAT reporter (Fig. 4). Cells were co-transfected with PPAR $\gamma, \operatorname{RXR} \alpha$, GHR and STAT5A, stimulated with BRL49653 and treated with $\mathrm{GH}$ together with increasing concentrations of p300. Increasing the concentration of p300 from 0 to $1.0 \mu \mathrm{g}$ reduced the inhibitory effect of $\mathrm{GH}$ from 60 to $30 \%$ (Fig. 4, bar 5). Increasing the concentration of p300 from $1 \cdot 0$ to $5 \cdot 0 \mu \mathrm{g}$ did not reduce the effect of $\mathrm{GH}$ any further (data not shown). This result shows that p300 can partially suppress the inhibitory effect of $\mathrm{GH}$ in a dose-dependent manner.

Figure 3 Effects of GH on the aP2 520 bp promoter. HEK 293 cells were transiently transfected with $0.5 \mu \mathrm{g}$ of the internal standard (SV40- $\beta$-gal) and $0.5 \mu \mathrm{g}$ of the $520 \mathrm{bp}$ aP2-CAT reporter gene. Co-expression of cDNA encoding PPAR $\gamma(0.5 \mu \mathrm{g}), \operatorname{RXR} \alpha(1.0 \mu \mathrm{g})$, GHR $(2.25 \mu \mathrm{g})$, various STAT5 expression vectors and stimulation of cells with BRL49653 $(0 \cdot 1 \mu \mathrm{M})$ and/or GH $(20 \mathrm{nM})$ are specified below graphs. Cells were cultured approximately $36 \mathrm{~h}$ before harvest. Transfections were done in duplicates and CAT activity was normalized to $\beta$-galactosidase activities. Error bars indicate S.D. (A) Cells were either transfected with the $520 \mathrm{bp}$ aP2-CAT reporter alone (bar 1) or in the presence of PPAR $\gamma$, $\mathrm{RXR} \alpha$ or BRL49653 in the absence (bar 2) or presence of GHR, STAT5A $(0.5 \mu \mathrm{g})$ (bars 3 and 4 ) and treated with GH (bar 4). CAT activities are presented as fold induction of transcriptional activity relative to 1 for cells transfected with the 520 bp aP2-CAT reporter alone $(n=8)$. (B) Cells transfected with 520 bp aP2-CAT, PPAR $\gamma, R X R \alpha$ or GHR and stimulated with BRL49653 were either not treated (bar 1) or treated with GH (bar 2). Cells were co-transfected with either STAT5A $(0.5 \mu \mathrm{g})$ (bars 3 and 4$)$ or with STAT5B $(0.5 \mu \mathrm{g})$ (bars 5 and 6 ) in the absence or presence of GH (bars 4 and 6). CAT activities are presented as percent transcriptional activity relative to $100 \%$ for cells transfected with the $520 \mathrm{bp}$ aP2-CAT reporter, PPAR $\gamma$, RXR $\alpha, G H R$, indicated STAT5 cDNA and stimulated with BRL49653 $(n=3)$. (C) Cells were co-transfected with STAT5A wt in the absence or presence of $20 \mathrm{nM} \mathrm{GH}$ (bars 1 and 2) (representing bars 5 and 6 of (B)) or co-transfected with the mutants STAT5A Y964F $(1.0 \mu \mathrm{g})$ (bars 3 and 4 ) or STAT5A ${ }^{\Delta 749}(1.0 \mu \mathrm{g})$ (bars 5 and 6 ) and cells were either not treated or treated with $\mathrm{GH}$ (bars 4 and 6). CAT activities are presented as percent transcriptional activity relative to $100 \%$ for cells transfected with the $520 \mathrm{bp}$ aP2-CAT reporter, PPAR 2 , RXR $\alpha$, GHR or STAT5A and stimulated with BRL49653 $(n=4)$. 


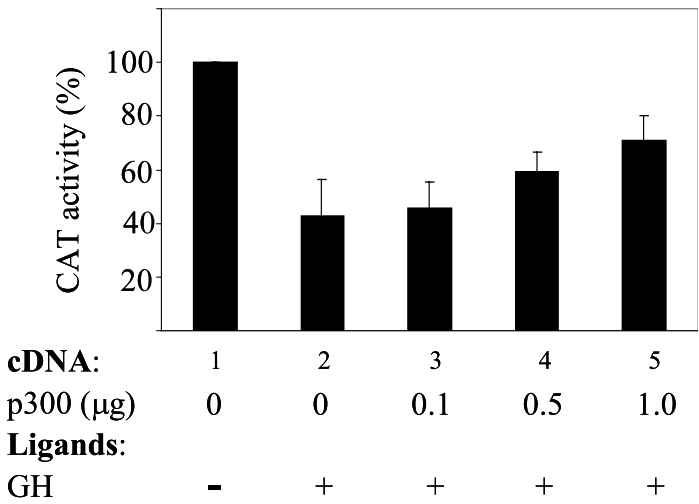

Figure 4 Increasing concentrations of p300 partly reverse the inhibitory effect of GH. HEK 293 cells were transiently transfected with $0.5 \mu \mathrm{g}$ of the internal standard (SV40- $\beta$-gal) and the $520 \mathrm{bp}$ aP2-CAT reporter $(0.5 \mu \mathrm{g})$, PPAR $\gamma(0.5 \mu \mathrm{g}), \mathrm{RXR} \alpha(1.0 \mu \mathrm{g}), \mathrm{GHR}(2.25 \mu \mathrm{g})$ and STAT5A $(0.5 \mu \mathrm{g})$, stimulated with $0.1 \mu \mathrm{M}$ BRL49653 and either not treated or treated with $20 \mathrm{nM} \mathrm{GH}$. Cells were co-transfected with increasing concentrations of p300 as indicated. Transfections were done in duplicates and cells were cultured approximately $36 \mathrm{~h}$ before harvest. CAT activities are presented as percent transcriptional activity relative to $100 \%$ for cells transfected with the 520 bp aP2-CAT reporter, PPAR $\gamma$, $\mathrm{RXR} \alpha, \mathrm{GHR}, \mathrm{STAT5A}$ and stimulated with BRL49653 $(n=3)$. Error bars indicate S.D.

\section{Discussion}

GH has been shown to play a critical role in regulating adipose tissue homeostasis in vivo (Donahue \& Beamer 1993, Pomp et al. 1996, Eisen et al. 1998, Ikeda et al. 1998, Lauterio et al. 1998, Frick et al. 2001). We have previously shown that $\mathrm{GH}$ inhibits the differentiation of primary adipocytes and that this effect is primarily exerted through the repression of genes required for terminal differentiation (Hansen et al. 1998). Although other growth factors such as epidermal growth factor and platelet-derived growth factor have been shown to antagonize PPAR $\gamma$-activated adipogenesis via a MAP kinase-dependent mechanism (Adams et al. 1997, Font et al. 1997), the inhibition of primary adipocytes by GH does not require the MAP kinase pathway (Hansen et al. 1998). In this study, we provide evidence to suggest that the inhibitory effect of $\mathrm{GH}$ is mediated via STAT5. First, we show that GH induces tyrosine phosphorylation, nuclear translocation and DNA binding of STAT5 in primary preadipocytes. Secondly, we show that GH-activated STAT5 serves as a repressor of the PPAR $\gamma$-stimulated $520 \mathrm{bp}$ aP2 promoter activity. In fact, the inhibitory effect of $\mathrm{GH}$ was found to be dependent on the presence of STAT5.

There is now considerable evidence that STAT5 can function as a transcriptional repressor. This includes inhibition of NF-אB (Luo \& Yu-Lee 2000), GR (Stocklin et al. 1996) and PPAR $\alpha, \operatorname{PPAR} \delta$ and PPAR $\gamma$ (Zhou \& Waxman 1999a,b). Although tyrosine phosphorylation of STAT5 appears to be essential for its activity, there does not appear to be a unifying mechanism of downstream signalling. For example, depending upon the target, repression may or may not require either the STAT5 transactivation domain or a direct interaction between STAT5 and the transcription factor it is repressing (Stocklin et al. 1996, Luo \& Yu-Lee 1997). Given this heterogeneity, we also investigated the mechanism by which STAT5 mediates GH-dependent repression of aP2. First, we showed that mutation of tyrosine 694 was sufficient to abolish STAT5 function. Thus, consistent with the previous studies (Luo \& Yulee 1997, Pfitzner et al. 1998, Zhou \& Waxman 1999a), tyrosine phosphorylation and presumably nuclear localization of STAT5 is essential for its repressive activity. Secondly, we tested whether STAT5 might form a direct complex with PPAR $\gamma$, the presumed target of this repressive effect. Although we used two different approaches, we were unable to detect any evidence for an interaction between $\mathrm{GH}$ induced STAT5 and PPAR $\gamma$. Clearly, we cannot rule out the possibility that this complex exists in vivo but is destroyed during the preparation of nuclear extracts. However, this finding is entirely consistent with the previous observations that STAT5 represses the ability of PPAR $\alpha$ to activate transcription in transient transfection assays without any evidence of direct interaction (Zhou \& Waxman $1999 a, b)$. Thus, in contrast to the direct binding and repression of GR, STAT5 appears to inhibit PPAR $\gamma$ through an indirect mechanism, more analogous to that reported for NF-אB (Luo \& Yu-Lee 2000).

To further establish the mechanism of inhibition, we determined how this related to STAT5's transcriptional properties. Consistent with the transfection studies of Zhou \& Waxman (1999a), we found that a C-terminal truncated STAT5A ${ }^{\triangle 749}$ lacking the transactivation domain was able to mediate the GH-dependent inhibition 
of our aP2 reporter. Hence, transactivation by STAT5A and thereby downstream gene expression induced by STAT5A is fully dispensable for the inhibitory effect of GH. Given this finding, we were surprised to find that overexpression of p300 can partially suppress, although not completely block, STAT5's inhibitory effect. It is entirely possible that p300 is acting in an indirect manner to increase global transcription and therefore to increase the activity of PPAR $\gamma$. Alternatively, since both the N-terminal and C-terminal domains of STAT1 have been shown to interact with CBP/p300 (Zhang et al. 1996), it is possible that STAT5 is acting to repress transcription by competing with the limiting pools of $\mathrm{CBP} / \mathrm{p} 300$ or other transcriptional co-activators. This would explain how the STAT5A ${ }^{\Delta 749}$ could affect PPAR $\gamma$-mediated transcription by sequestering transcriptional co-activators. If indeed the $\mathrm{N}$-terminal domain of STAT5 is able to interact with $\mathrm{CBP} / \mathrm{p} 300$, as is the case for STAT1, this could cause the inhibition of aP2 transcription in response to GH. Importantly, since we were unable to completely override the effect of STAT5 by p300 overexpression, STAT5's repressive properties must be at least partially independent of p300 binding. Clearly, this could be through the sequestration of some other, limiting co-activator or through an unrelated mechanism. The inhibitory effect of $\mathrm{GH}$ on the differentiation of primary rat preadipocytes is in striking contrast to the finding that $\mathrm{GH}$ acts a positive regulator in the adipogenic conversion of the 3T3-F442A and NIH-3T3 mouse cell lines (Morikawa et al. 1982, Clarkson et al. 1995). Interestingly, there is considerable evidence suggesting that STAT5 acts in a positive manner in these adipogenic cell line systems. First, the JAK2/STAT5 signalling pathway is required for GH-dependent differentiation of 3T3-F442A preadipocytes (Yarwood et al. 1999). Secondly, STAT5 mediates adipocyte differentiation of NIH-3T3 and 3T3-L1 cells upon stimulation by the GH-related cytokine prolactin (Nanbu-Wakao et al. 2000, 2002). Finally, STAT5 expression is induced in a PPAR $\gamma$ ligand-dependent manner and seems to be tightly linked to the adipogenic conversion of 3T3-L1 cells (Stephens et al. 1996, 1999). Combined with our findings in primary preadipocytes, these observations suggest that STAT5 plays an important role in mediating the effects of $\mathrm{GH}$ on adipocyte differentiation.
Moreover it raises the question as to whether cytokine-induced STAT5 affects adipogenesis differently depending on species and the stage of adipocyte differentiation. Importantly, it was recently shown that antagonism of $\operatorname{PPAR} \gamma$ activity ameliorated high fat diet-induced obesity and insulin resistance (Yamauchi et al. 2001). A better understanding of the mechanisms behind functional antagonism of PPAR $\gamma$ consequently has important therapeutic potential for treatment of obesity and related metabolic syndromes.

\section{Acknowledgements}

We thankfully acknowledge Drs Bruce M Spiegelman, Jan Fleckner, Bernd Groner, Richard Goodman and Gunnar Norstedt for plasmids. We also wish to thank Drs Jacqueline A Lees and Elisabeth D Galsgaard for valuable comments to the manuscript. We acknowledge excellent technical assistance by Tine Pedersen. The Danish Academy of Technical Sciences supported H E R.

\section{References}

Adams M, Reginato MJ, Shao D, Lazar MA \& Chatterjee VK 1997 Transcriptional activation by peroxisome proliferator-activated receptor gamma is inhibited by phosphorylation at a consensus mitogen-activated protein kinase site. Fournal of Biological Chemistry 272 5128-5132

Argetsinger LS, Campbell GS, Yang X, Witthuhn BA, Silvennoinen O, Ihle JN \& Carter-Su C 1993 Identification of JAK2 as a growth hormone receptor-associated tyrosine kinase. Cell $\mathbf{7 4}$ 237-244.

Campbell GS, Meyer DJ, Raz R, Levy DE, Schwartz J \& Carter-Su C 1995 Activation of acute phase response factor (APRF)/Stat3 transcription factor by growth hormone. Fournal of Biological Chemistry $2703974-3979$.

Carter-Su C, Stubbart JR, Wang XY, Stred SE, Argetsinger LS \& Shafer JA 1989 Phosphorylation of highly purified growth hormone receptors by a growth hormone receptor-associated tyrosine kinase. Fournal of Biological Chemistry 264 18654-18661.

Chakravarti D, Lamorte VJ, Nelson MC, Nakajima T, Schulman IG, Juguilon H, Montminy M \& Evans RM 1996 Role of CBP/p300 in nuclear receptor signalling. Nature 383 99-103.

Chen C \& Okayama H 1987 High-efficiency transformation of mammalian cells by plasmid DNA. Molecular and Cellular Biology 7 2745-2752.

Christy RJ, Yang VW, Ntambi JM, Geiman DE, Landschulz WH, Friedman AD, Nakabeppu Y, Kelly TJ \& Lane MD 1989 Differentiation-induced gene expression in 3T3-L1 preadipocytes: CCAAT/enhancer binding protein interacts with and activates the promoters of two adipocyte-specific genes. Genes and Development 3 1323-1335.

Clarkson RW, Chen CM, Harrison S, Wells C, Muscat GE \& Waters MJ 1995 Early responses of trans-activating factors to growth hormone in preadipocytes: differential regulation of 
CCAAT enhancer-binding protein-beta (C/EBP beta) and C/EBP delta. Molecular Endocrinology 9 108-120.

Donahue LR \& Beamer WG 1993 Growth hormone deficiency in 'little' mice results in aberrant body composition, reduced insulin-like growth factor-I and insulin-like growth factor-binding protein-3 (IGFBP-3), but does not affect IGFBP-2, -1 or -4. Fournal of Endocrinology 136 91-104.

Eisen EJ, Peterson CB, Parker IJ \& Murray JD 1998 Effects of zinc ion concentration on growth, fat content and reproduction in oMTla-oGH transgenic mice. Growth, Development, and Aging 62 173-186.

Fajas L, Schoonjans K, Gelman L, Kim JB, Najib J, Martin G, Fruchart JC, Briggs M, Spiegelman BM \& Auwerx J 1999 Regulation of peroxisome proliferator-activated receptor gamma expression by adipocyte differentiation and determination factor 1 /sterol regulatory element binding protein 1 . Implications for adipocyte differentiation and metabolism. Molecular and Cellular Biology 19 5495-5503.

Font de J, Porras A, Ahn N \& Santos E 1997 Mitogen-activated protein kinase activation is not necessary for, but antagonizes, 3T3-L1 adipocytic differentiation. Molecular and Cellular Biology 17 6068-6075.

Forman BM, Tontonoz P, Chen J, Brun RP, Spiegelman BM \& Evans RM 1995 15-deoxy-delta(12,14)-prostaglandin $\mathrm{j}(2)$ is a ligand for the adipocyte determination factor PPAR-gamma. Cell 83 803-812.

Freytag SO, Paielli DL \& Gilbert JD 1994 Ectopic expression of the CCAAT/enhancer-binding protein alpha promotes the adipogenic program in a variety of mouse fibroblastic cells. Genes and Development 8 1654-1663.

Frick F, Bohlooly Y, Linden D, Olsson B, Tornell J, Eden S \& Oscarsson J 2001 Long-term growth hormone excess induces marked alterations in lipoprotein metabolism in mice. American Fournal of Physiology. Endocrinology and Metabolism 281 E1230-E1239.

Galsgaard ED, Gouilleux F, Groner B, Serup P, Nielsen JH \& Billestrup N 1996 Identification of a growth hormone-responsive STAT5-binding element in the rat insulin-1 gene. Molecular Endocrinology $10652-660$.

Ge K, Guermah M, Yuan CX, Ito M, Wallberg AE, Spiegelman BM \& Roeder RG 2002 Transcription coactivator TRAP220 is required for PPAR gamma 2-stimulated adipogenesis. Nature 417 563-567.

Gelman L, Zhou GC, Fajas L, Raspe E, Fruchart JC \& Auwerx J 1999 p300 interacts with the N- and C-terminal part of PPAR gamma 2 in a ligand-independent and -dependent manner, respectively. Fournal of Biological Chemistry 274 7681-7688.

Gouilleux F, Wakao H, Mundt M \& Groner B 1994 Prolactin induces phosphorylation of Tyr694 of Stat5 (MGF), a prerequisite for DNA binding and induction of transcription. EMBO Fournal 13 $4361-4369$

Graves RA, Tontonoz P, Ross SR \& Spiegelman BM 1991 Identification of a potent adipocyte-specific enhancer: involvement of an NF-1-like factor. Genes and Development 5 428-437.

Graves RA, Tontonoz P \& Spiegelman BM 1992 Analysis of a tissue-specific enhancer: ARF6 regulates adipogenic gene expression. Molecular and Cellular Biology 123313.

Gronowski AM, Zhong Z, Wen Z, Thomas MJ, Darnell JE \& Rotwein $\mathrm{P} 1995$ In vivo growth hormone treatment rapidly stimulates the tyrosine phosphorylation and activation of Stat3. Molecular Endocrinology 9 171-177.

Hansen JA, Hansen LH, Kopchick JJ, Gouilleux F, Groner B, Nielsen JH, Perregaard AM, Galsgaard ED \& Billestrup N 1997 The role of growth hormone receptor tyrosine phosphorylation in Stat5 activation. Fournal of Molecular Endocrinology 18 213-221.

Hansen LH, Madsen B, Teisner B, Nielsen JH \& Billestrup N 1998 Characterization of the inhibitory effect of growth-hormone on primary preadipocyte differentiation. Molecular Endocrinology 12 $1140-1149$.

Harp JB, Franklin D, Vanderpuije AA \& Gimble JM 2001

Differential expression of signal transducers and activators of transcription during human adipogenesis. Biochemical and Biophysical Research Communications 281 907-912.

Ihle JN 2001 The Stat family in cytokine signaling. Current Opinion in Cellular Biology 13 211-217.

Ikeda A, Chang KT, Matsumoto Y, Furuhata Y, Nishihara M, Sasaki F \& Takahashi M 1998 Obesity and insulin-resistance in human growth-hormone transgenic rats. Endocrinology 139 3057-3063.

Johannsson G, Marin P, Lonn L, Ottosson M, Stenlof K, Bjorntorp P, Sjostrom L \& Bengtsson BA 1997 Growth hormone treatment of abdominally obese men reduces abdominal fat mass, improves glucose and lipoprotein metabolism, and reduces diastolic blood pressure. Fournal of Clinical Endocrinology and Metabolism 82 $727-734$

Kamei Y, Xu L, Heinzel T, Torchia J, Kurokawa R, Gloss B, Lin SC, Heyman RA, Rose DW, Glass CK et al. 1996 A CBP integrator complex mediates transcriptional activation and AP-1 inhibition by nuclear receptors. Cell 85 403-414.

Lauterio TJ, Barkan A, DeAngelo M, DeMott-Friberg R \& Ramirez R 1998 Plasma growth hormone secretion is impaired in obesityprone rats before onset of diet-induced obesity. American Fournal of Physiology 275 E6-E11.

Lehmann JM, Moore LB, Smith-Oliver TA, Wilkison WO, Willson TM \& Kliewer SA 1995 An antidiabetic thiazolidinedione is a high affinity ligand for peroxisome proliferator-activated receptor gamma (PPAR gamma). Fournal of Biological Chemistry 270 12953-12956.

Luo G \& Yu-Lee L 2000 Stat5b inhibits NFkappaB-mediated signaling. Molecular Endocrinology 14 114-123.

Luo G \& Yu-Lee L 1997 Transcriptional inhibition by stat5 differential activities at growth-related versus differentiationspecific promoters. Fournal of Biological Chemistry 272 2684126849.

Meyer DJ, Campbell GS, Cochran BH, Argetsinger LS, Larner AC, Finbloom DS, Carter-Su C \& Schwartz J 1994 Growth hormone induces a DNA binding factor related to the interferon-stimulated 91-kDa transcription factor. Fournal of Biological Chemistry 269 4701-4704.

Morikawa M, Nixon T \& Green H 1982 Growth hormone and the adipose conversion of 3T3 cells. Cell 29 783-789.

Nanbu-Wakao R, Fujitani Y, Masuho Y, Muramatu M \& Wakao H 2000 Prolactin enhances CCAAT enhancer-binding protein-beta (C/EBP beta) and peroxisome proliferator-activated receptor gamma (PPAR gamma) messenger RNA expression and stimulates adipogenic conversion of NIH-3T3 cells. Molecular Endocrinology 14 307-316.

Nanbu-Wakao R, Morikawa Y, Matsumura I, Masuho Y, Muramatsu MA, Senba E \& Wakao H 2002 Stimulation of 3T3-L1 adipogenesis by signal transducer and activator of transcription 5. Molecular Endocrinology 16 1565-1576.

Pfitzner E, Jahne R, Wissler M, Stoecklin E \& Groner B 1998 P300/CREB-binding protein enhances the prolactin-mediated transcriptional induction through direct interaction with the transactivation domain of stat5, but does not participate in the stat5-mediated suppression of the glucocorticoid response. Molecular Endocrinology 12 1582-1593.

Pomp D, Oberbauer AM \& Murray JD 1996 Development of obesity following inactivation of a growth-hormone transgene in mice. Transgenic Research 5 13-23.

Rosen ED, Sarraf P, Troy AE, Bradwin G, Moore K, Milstone DS, Spiegelman BM \& Mortensen RM 1999 PPAR gamma is required for the differentiation of adipose tissue in vivo and in vitro. Molecular Cell 4 611-617. 
Rosen ED, Walkey CJ, Puigserver P \& Spiegelman BM 2000 Transcriptional regulation of adipogenesis. Genes and Development $\mathbf{1 4}$ 1293-1307.

Salomon F, Cuneo RC, Hesp Ri \& Sonksen PH 1989 The effects of treatment with recombinant human growth hormone on body composition and metabolism in adults with growth hormone deficiency. New England Fournal of Medicine 321 1797-1803.

Schoonjans K, Peinado-Onsurbe J, Lefebvre AM, Heyman RA, Briggs M, Deeb S, Staels B \& Auwerx J 1996 PPARalpha and PPARgamma activators direct a distinct tissue-specific transcriptional response via a PPRE in the lipoprotein lipase gene. EMBO Fournal 15 5336-5348.

Smit LS, Meyer DJ, Billestrup N, Norstedt G, Schwartz J \& Carter-Su C 1996 The role of the growth hormone $(\mathrm{GH})$ receptor and JAK 1 and JAK2 kinases in the activation of Stats 1, 3, and 5 by GH. Molecular Endocrinology 10 519-533.

Smit LS, Vanderkuur JA, Stimage A, Han Y, Luo G, Yu-Lee LY, Schwartz J \& Carter-Su C 1997 Growth hormone-induced tyrosyl phosphorylation and deoxyribonucleic acid binding activity of Stat5A and Stat5B. Endocrinology 138 3426-3434.

Stephens JM, Morrison RF \& Pilch PF 1996 The expression and regulation of STATs during 3T3-L1 adipocyte differentiation. Fournal of Biological Chemistry 271 10441-10444.

Stephens JM, Morrison RF, Wu Z \& Farmer SR 1999 PPARgamma ligand-dependent induction of STAT1, STAT5A, and STAT5B during adipogenesis. Biochemical and Biophysical Research Communications 262 216-222.

Stocklin E, Wissler M, Gouilleux F \& Groner B 1996 Functional interactions between stat 5 and the glucocorticoid receptor. Nature $383726-728$

Teglund S, Mckay C, Schuetz E, Vandeursen JM, Stravopodis D, Wang DM, Brown M, Bodner S, Grosveld G \& Ihle JN 1998 Stat5a and stat5b proteins have essential and nonessential, or redundant, roles in cytokine responses. Cell 93 841-850.

Tontonoz P, Graves RA, Budavari AI, Erdjument-Bromage H, Lui M, Hu E, Tempst P \& Spiegelman BM 1994a Adipocyte-specific transcription factor ARF6 is a heterodimeric complex of two nuclear hormone receptors, PPAR gamma and RXR alpha. Nucleic Acids Research 22 5628-5634.

Tontonoz P, Hu E, Graves RA, Budavari AI \& Spiegelman BM $1994 b$ mPPAR gamma 2: tissue-specific regulator of an adipocyte enhancer. Genes and Development 8 1224-1234.

Tontonoz P, Hu E \& Spiegelman BM 1994c Stimulation of adipogenesis in fibroblasts by PPAR gamma 2, a lipid-activated transcription factor. Cell 79 1147-1156.

Tontonoz P, Hu E, Devine J, Beale EG \& Spiegelman BM 1995 PPAR gamma 2 regulates adipose expression of the phosphoenolpyruvate carboxykinase gene. Molecular and Cellular Biology 15 351-357.

de Vos AM, Ultsch M \& Kossiakoff AA 1992 Human growth hormone and extracellular domain of its receptor: crystal structure of the complex. Science 255 306-312.
Wabitsch M, Braun S, Hauner H, Heinze E, Ilondo MM, Shymko R, Demeyts P \& Teller WM 1996 Mitogenic and antiadipogenic properties of human growth-hormone in differentiating human adipocyte precursor cells in primary culture. Pediatric Research $\mathbf{4 0}$ $450-456$.

Wood TJ, Sliva D, Lobie PE, Pircher TJ, Gouilleux F, Wakao H, Gustafsson JA, Groner B, Norstedt G \& Haldosen LA 1995 Mediation of growth hormone-dependent transcriptional activation by mammary gland factor/Stat 5. Fournal of Biological Chemistry 270 9448-9453.

Wu Z, Rosen, ED, Brun R, Hauser S, Adelmant G, Troy AE, McKeon C, Darlington GJ \& Spiegelman BM 1999 Cross-regulation of $\mathrm{C} / \mathrm{EBP}$ alpha and PPAR gamma controls the transcriptional pathway of adipogenesis and insulin sensitivity. Molecular Cell 3 151-158.

Xu BC, Chen WY, Gu T, Ridgway D, Wiehl P, Okada S \& Kopchick JJ 1995 Effects of growth-hormone antagonists on 3T3-F442A preadipocyte differentiation. Fournal of Endocrinology 146 131-139.

Yamauchi T, Waki H, Kamon J, Murakami K, Motojima K, Komeda K, Miki H, Kubota N, Terauchi Y, Tsuchida A et al. 2001 Inhibition of RXR and PPARgamma ameliorates diet-induced obesity and type 2 diabetes. Fournal of Clinical Investigation 108 1001-1013.

Yarwood SJ, Sale EM, Sale GJ, Houslay MD, Kilgour E \& Anderson NG 1999 Growth hormone-dependent differentiation of 3T3-F442A preadipocytes requires Janus kinase/signal transducer and activator of transcription but not mitogen-activated protein kinase or p70 S6 kinase signaling. Fournal of Biological Chemistry 274 8662-8668.

Zhang JJ, Vinkemeier U, Gu W, Chakravarti D, Horvath CM \& Darnell JE 1996 Two contact regions between Statl and CBP/ p300 in interferon gamma signaling. PNAS 93 15092-15096.

Zhou YC \& Waxman DJ 1999a Cross-talk between janus kinase-signal transducer and activator of transcription (JAK-STAT) and peroxisome proliferator-activated receptor-alpha (PPARalpha) signaling pathways. Growth hormone inhibition of pparalpha transcriptional activity mediated by stat5b. Fournal of Biological Chemistry 2742672 2681.

Zhou YC \& Waxman DJ 1999 b STAT5b down-regulates peroxisome proliferator-activated receptor alpha transcription by inhibition of ligand-independent activation function region-1 trans-activation domain. Fournal of Biological Chemistry 274 $29874-29882$.

Zhu Y, Qi C, Jain S, Rao, MS \& Reddy JK 1997 Isolation and characterization of $\mathrm{PBP}$, a protein that interacts with peroxisome proliferator-activated receptor. Fournal of Biological Chemistry $\mathbf{2 7 2}$ 25500-25506.

Received in final form 20 November 2002 Accepted 16 December 2002 